\title{
Partisipasi pendidikan Kristiani di ruang publik dalam menunjang deradikalisasi
}

Jeniffer Pelupessy Wowor

Fakultas Teologi Universitas Kristen Duta Wacana, Yogyakarta jeniffer@staff.ukdw.ac.id

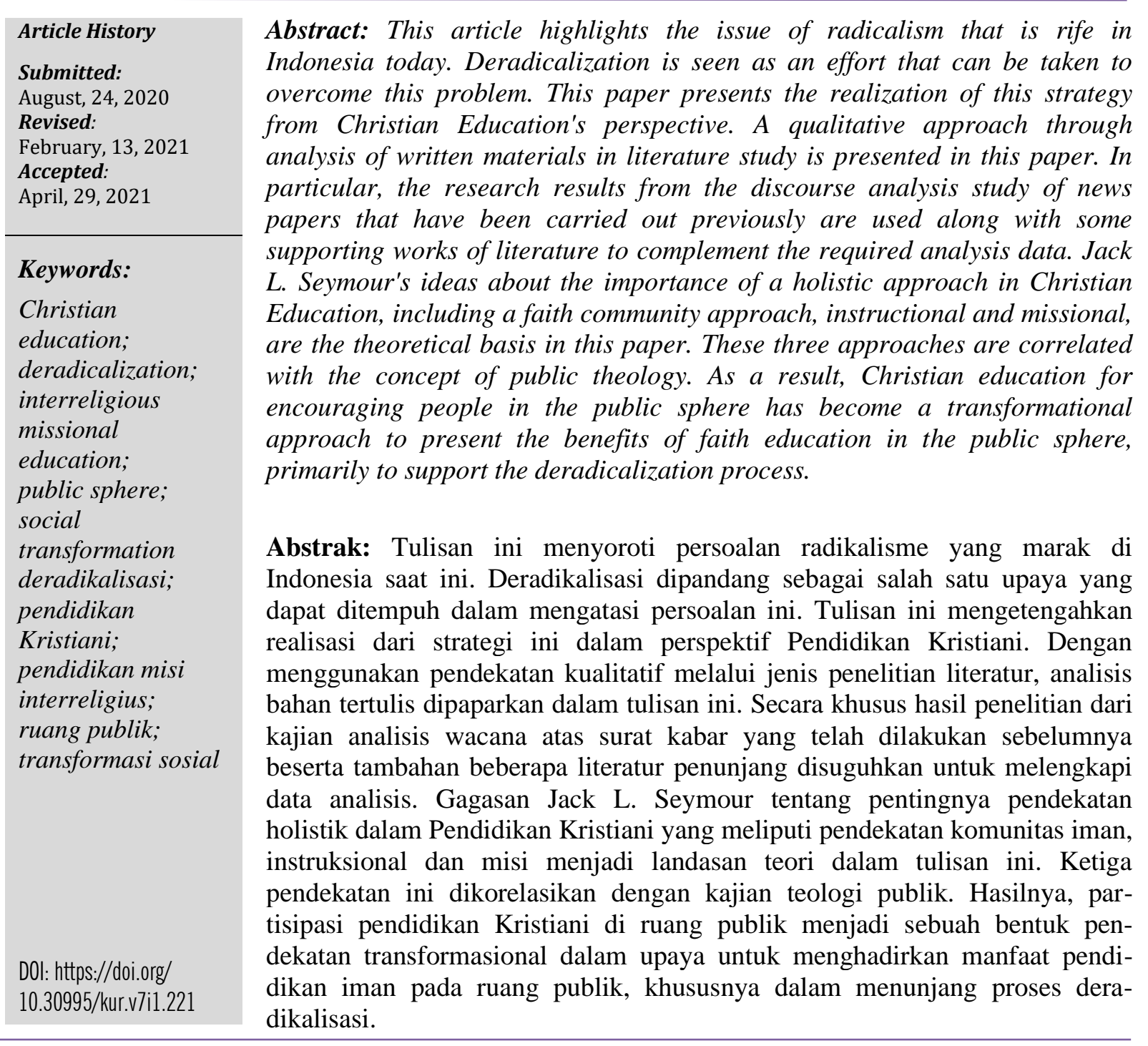

\section{Pendahuluan}

Radikalisme adalah persoalan yang saat ini marak di Indonesia. Sekalipun ada banyak penyebab dari radikalisme, namun salah satu penyebab yang penting untuk diperhatikan adalah terorisme global. Istilah terorisme, teroris, dan teror berasal dari bahasa Latin terror, dan diturunkan dari kata terrere, artinya "menakut-nakuti" dan terkait dengan bahasa Yunani trein, yang berarti "melepaskan diri dari ketakutan" sehingga teror dapat dipahami sebagai keadaan ketakutan yang mendalam dan bisa lahir dari tindakan kekerasan manusia (sekalipun 
bisa juga memiliki penyebab yang lain). ${ }^{1}$ Dengan demikian, terorisme dapat dipahami sebagai penggunaan sistematis dari ketakutan sebagai sebuah sarana kekerasan dan paksaan, termasuk upaya untuk menciptakan sebuah atmoster ketakutan dan kekerasan, seperti sebuah reign of terror. ${ }^{2}$ Radikalisme dan intoleransi memiliki korelasi dengan patologi komunikasi. Dalam praksis komunikasi yang baik, upaya saling memahami dapat terjalin. Saat kegagalan komunikasi terjadi (distorsi), proses saling tukar-menukar perspektif secara mutual tidak dapat dapat dilakukan. Hal ini menimbulkan perasaan asing dan terasing yang dapat mengarah pada kekerasan. ${ }^{3}$

Jürgen Habermas mengaitkan fenomena terorisme global dengan fundamentalisme agama. ${ }^{4}$ Terorisme global adalah bagian dari tindakan penolakan fundamentalisme agama yang menolak modernitas dan dengan demikian tidak dapat menerima toleransi religius dan konteks kepelbagaian. ${ }^{5}$ Menurut Habermas, agama dalam pemikiran postmetafisik seyogianya dapat membawa kekuatan argumentasi dan bukan kekuatan kekerasan. ${ }^{6}$ Dalam konteks yang demikian, reformulasi terhadap ajaran agama sehingga dapat saling belajar satu sama lain. Dengan demikian, dialog yang sehat antar pemeluk agama dan institusi masyarakat di ruang publik menjadi penting untuk diperhatikan.

Berdasarkan pemahaman ini maka dalam konteks pendidikan iman, komunitaskomunitas religius kiranya dapat belajar untuk saling melengkapi sekaligus merekonstruksi setiap hal yang terkait dengan apa yang diyakini. Inilah makna luhur toleransi yang membuat kita menghormati ajaran atau kepercayaan yang berbeda. Perbedaan pendapat tidak harus menjadi sesuatu yang dipersoalkan, namun jangan sampai hal ini membawa pada prasangka negatif yang memecah belah. Hal ini harus dimulai dari dalam komunitas religius itu sendiri. Dalam kerangka pemahaman inilah maka deradikalisasi dapat dimaknai secara komprehensif. Deradikalisasi tidak hanya menjadi upaya untuk mengatasi radikalisme melainkan juga mencegahnya. Deradikalisasi dalam hal ini tidak hanya dimaknai sebagai pendekatan yang top down, dimulai oleh pemerintah atau apparat penegak hukum, melainkan juga merangkul semua lapisan masyarakat dan aspek kehidupan yang dijalani (bottom up). Inilah pemahaman tentang deradikalisasi yang menjiwai seluruh gagasan dalam tulisan ini.

Gagasan tentang pentingnya partisipasi umat beragama di ruang publik yang mendasari tulisan ini adalah sebuah tindak lanjut dari kajian analisis wacana deradikalisasi dalam surat kabar yang pernah penulis lakukan sebelumnya bersama dengan tim peneliti dari Fakultas Teologi Universitas Kristen Duta Wacana. Dalam penelitian tersebut, pemikiran Anis Badara tentang analisis wacana diaplikasikan dalam teks-teks berita dari surat kabar Kompas, Jawa Pos, dan Kedaulatan Rakyat. Hasil penelitian kemudian dikaji dari perspektif teologi praktis yang memuat empat aspek, descriptive-empirical task (apa realita yang terjadi?), interpretivetask (mengapa hal ini terjadi?), normative task (apa kajian teologis terhadap realita atau

${ }^{1}$ Constantinus Fatlolon, Masalah Terorisme Global: Dalam Konteks Teori Habermas tentang Kolonisasi Dunia Kehidupan oleh Sistem Modern (Yogyakarta: Kanisius, 2016), 58-59.

${ }^{2}$ Fatlolon, 59.

${ }^{3}$ Fatlolon, 68.

${ }^{4}$ Fatlolon, 68.

${ }^{5}$ Fatlolon, 68-69.

${ }^{6}$ Fatlolon, 95. 
persoalan yang muncul?) dan pragmatic task (bagaimana wujud strategi atau aksi yang dapat diwujudkan terkait dengan kajian yang telah dilakukan?). Lebih lanjut, hasil kajian ini telah dipublikasikan dalam sebuah buku yang berjudul, "Wacana Deradikalisasi dalam Surat Kabar dan Kajian Teologi Praktis." 7

Yang menarik, berdasarkan tinjauan yang muncul dalam interpretive dan normative task, strategi atau rekomendasi yang muncul dan memiliki implikasi dalam deradikalisasi di antaranya adalah tentang pentingnya upaya dari kelompok-kelompok agama dalam konteks kepelbagaian untuk menerjemahkan bahasa teologis mereka yang partikular ke dalam ungkapan yang dapat diterima secara rasional oleh publik. ${ }^{8}$ Inilah permasalahan yang dihadapi saat ini untuk kemudian dapat ditindaklanjuti. Gagasan ini terkait dengan pemikiran Habermas mengenai "situasi epistemis" (epistemische Einstellung), keadaan ketika seorang pemeluk agama tetap berpegang pada kebenaran imannya, tapi tetap bersikap moderat di ruang publik. ${ }^{9}$ Inilah sikap epistemis seorang warga negara yang mengkomunikasikan iman dalam persoalan yang terjadi di tengah masyarakat, termasuk misalnya intoleransi dan radikalisme. Namun, keberhasilan upaya ini memang bergantung dari kemampuan agamaagama untuk menghubungkan kepercayaan mereka dalam cara berefleksi diri terhadap ajaranajaran agama lain dan pengetahuan sekular yang bisa jadi bertentangan dengan klaim kebenaran mereka sendiri. ${ }^{10}$ Di dalamnya terkandung solidaritas berdasarkan prinsip-prinsip yang tidak bertentangan hak asasi manusia dalam kehidupan di tengah masyarakat.

Dalam konteks komunitas Kristen, dapat dikatakan bahwa partisipasi umat Kristen di ruang publik menjadi bagian penting dalam proses deradikalisasi dalam rangka mengatasi persoalan radikalisme yang dihadapi bangsa Indonesia saat ini. Tulisan ini hendak menunjukkan betapa pentingnya peran Pendidikan Kristiani untuk menunjang partisipasi umat Kristen di ruang publik. Gagasan Jack L. Seymour tentang pentingnya pendekatan holistik dalam Pendidikan Kristiani yang meliputi pendekatan komunitas iman, instruksional dan misi menjadi landasan teori dalam tulisan ini. Ketiga pendekatan ini dikorelasikan dengan kajian teologi publik. Hasilnya, pendidikan kristiani di ruang publik menjadi sebuah bentuk pendekatan transformasional dalam upaya untuk menghadirkan manfaat pendidikan iman, dalam hal ini iman Kristen di ruang publik khususnya dalam menunjang proses deradikalisasi. Selain itu, pengembangan pemikiran dalam konteks lintas iman turut memperkaya hasil pembahasan dalam tulisan ini.

\section{Metode Penelitian}

Kajian dalam tulisan ini menggunakan model penelitian kualitatif melalui metode pengumpulan data yang berupa penelaahan terhadap dokumen tertulis. ${ }^{11}$ Sumber primer meliputi hasil

\footnotetext{
${ }^{7}$ Jeniffer F. P. Wowor dan Rena Sesaria Yudhita, Wacana Deradikalisasi dalam Surat Kabar dan Kajian Teologi Praktis (Yogyakarta: Duta Wacana University Press, 2019).

${ }^{8}$ Wowor dan Yudhita, 395.

${ }^{9}$ Gagasan Jürgen Habermas sebagaimana dikemukakan oleh F. Budi Hardiman dalam F. Budi Hardiman, Demokrasi dan Sentimentalitas: Dari “Bangsa Setan-Setan”, Radikalisme Agama sampai Post-Sekularisme (Yogyakarta: Kanisius, 2018), 205.

${ }^{10}$ Fatlolon, Masalah Terorisme Global: Dalam Konteks Teori Habermas tentang Kolonisasi Dunia Kehidupan oleh Sistem Modern, 81.

${ }^{11}$ Dèdè Oetomo, "Penelitian Kualitatif: Aliran dan Tema," dalam Metode Penelitian Sosial: Berbagai Alternatif Pendekatan, ed. Bagong Suyanto dan Sutinah, 3rd ed. (Jakarta: Kencana, 2007), 186.
} 
penelitian dari kajian analisis wacana atas surat kabar yang telah dilakukan penulis dan tim penelitian sebelumnya dalam buku Wacana Deradikalisasi dalam Surat Kabar dan Kajian Teologi Praktis beserta tambahan beberapa literatur penunjang disuguhkan untuk melengkapi data tentang latar belakang permasalahan dan analisis. Sumber primer berikutnya adalah gagasan Jack L. Seymour tentang pentingnya pendekatan holistik dalam Pendidikan Kristiani yang meliputi pendekatan komunitas iman, instruksional dan misi sebagai landasan teori dalam tulisan ini. Hasilnya, pendidikan kristiani untuk partisipasi di ruang publik menjadi sebuah bentuk pendekatan transformasional dalam upaya untuk menghadirkan manfaat pendidikan iman di ruang publik khususnya dalam menunjang proses deradikalisasi. Selain itu, pengembangan pemikiran Seymour dari penulis dalam konteks lintas iman turut memperkaya hasil pembahasan dalam tulisan ini.

\section{Pembahasan}

\section{Pelestarian Kultur Penindasan dalam Komunitas Iman}

Dalam perspektif Pendidikan Kristiani, tantangan terbesar dalam konteks ruang publik adalah realita dalam komunitas iman yang secara sadar ataupun tidak melestarikan penindasan dan intoleransi serta nilai-nilai kekerasan terhadap mereka yang dianggap berbeda (baca: berbeda agama dan pendapat). Mitzi J. Smith mengemukakan bahwa hal ini terkait erat dengan model pembelajaran yang menimbulkan kebencian, sikap fanatik dan eksklusif. ${ }^{12}$ Dengan demikian, komunitas Kristen perlu terlebih dahulu menyadari bahwa untuk dapat secara efektif bersuara lantang di ruang publik dan memberi perspektif yang konstruktif tentang isu-isu aktual, misalnya toleransi dan deradikalisasi maka perlu dikritisi apakah nilai-nilai itu telah diimplementasikan dalam komunitas imannya ataukah tidak. Hal ini penting untuk disadari karena seringkali, kita mengidentikkan radikalisme dengan para teroris atau bahkan agama tertentu (baca: Islam), namun sejauhmana kita sebagai komunitas Kristen bersikap kritis bahwa benih-benih radikalisme bisa saja kita serap atau lestarikan dalam bentuk yang berbeda di tengah komunitas umat Kristen sendiri. Kita tidak perlu menjadi teroris dan dipenjarakan untuk kemudian membuktikan bahwa radikalisme itu dihidupi. Ada banyak hal dengan muatan "radikalisme" yang bisa saja tidak kita sadari.

I Made Suardana mengemukakan bahwa tantangan dalam pelaksanaan Pendidikan Agama Kristen di tengah konteks kemajemukan yang ada di Indonesia adalah dominasi ego teologis doktrinal berbasis aliran gereja yang membuat perilaku fundamentalis amat kuat ditonjolkan. ${ }^{13}$ Oleh karena itu, transformasi yang dilakukan dalam ruang publik terkait erat dengan apa yang juga kita lakukan dalam dalam komunitas iman di mana kita adalah bagiannya. Terinspirasi dari gagasan Charles R. Foster, Mai-Anh Le Tran menunjukkan sebuah gambaran dari "pedagogi yang melanggengkan kekerasan" yang bisa jadi tetap lestari dalam komunitas iman. ${ }^{14}$ Hal ini terlihat dalam pemaparan tentang lima karakteristik dari

\footnotetext{
${ }^{12}$ Mitzi J. Smith, "US Colonial Missions to African Slaves: Catechizing Black Souls, Traumatizing the Black Psyche," dalam Mitzi J. Smith dan Jayachitra Lalitha (ed.), Teaching all Nations: Interrogating the Matthean Great Commision (2014), dikutip dalam Mai-Anh Le Tran, Reset the Heart: Unlearning Violence, Relearning Hope (Nashville: Abingdon Press, 2017), 48.

${ }^{13}$ I Made Suardana, "Mengurai Landasan Konseptual Pendidikan Agama Kristen Multikultural dalam Konteks Indonesia," Kurios 6, no. 2 (2020): 346, https://doi.org/https://10.30995/kur.v6i2.150.

14 Tran, Reset the Heart: Unlearning Violence, Relearning Hope, 50-52.
} 
pedagogi yang melanggengkan kekerasan yang kemudian penulis implikasikan dalam konteks persoalan radikalisme dan intoleransi yang diangkat dalam tulisan ini.

Pertama, kehilangan (atau manghapuskan) nilai-nilai yang penting dalam mengusung toleransi dan deradikalisasi. Pemahaman ini terkait dengan istilah mentacide, penghapusan memori historis. ${ }^{15}$ Kondisi ini bisa juga terkait dengan ketidakmampuan komunitas iman untuk meneruskan warisan imannya dalam mengusung toleransi dan mendukung deradikalisasi pada generasi berikutnya (misalnya kaum muda). Misalnya, ketika kurikulum dalam gereja tetap mengajarkan tentang superioritas Agama Kristen terhadap agama lain dan tetap mengusung intoleransi. Selain itu, hal ini juga bisa terkait dengan upaya sengaja yang dilakukan untuk memelihara intoleransi dengan tidak mengajarkan apa yang seharusnya diajarkan (misalnya tentang konsep keselamatan yang semestinya tidak dipahami secara eksklusif).

Kedua, pengajaran Alkitab yang tidak relevan. Alkitab dijadikan "senjata" untuk melanggengkan tindakan radikal/intoleran. Teks Alkitab yang diambil tanpa menganalisis konteks sehingga perilaku eksklusif dan intoleran seolah-olah didukung oleh ayat-ayat Alkitab. Misalnya saja ketika masing-masing kelompok yang terlibat konflik dalam gereja menggunakan ayat Alkitab untuk membela diri dan menyerang pihak lain.

Ketiga, tertawannya budaya yang kritis terhadap radikalisme dan intoleransi baik secara langsung maupun tidak langsung (diam, cari aman dan abai) yang membuat kedua hal ini justru bertumbuh subur. Konsep ini juga terkait dengan upaya menjaga status quo dalam proses pembelajaran di tengah komunitas iman sehingga tidak kritis terhadap realita yang dihadapi walaupun ketidakadilan terhampar jelas. Misalnya ketika gereja membangun komunitas eksklusif yang tidak peduli dengan persoalan radikalisme dan intoleransi di sekitarnya, bahkan bersikap intoleran dengan konteks kepelbagaian.

Keempat, penyelewengan tujuan Pendidikan Kristiani karena kehilangan kapasitas untuk keluar dari dominasi status quo. Persoalan kemanusiaan yang jelas-jelas terjadi tidak menjadi perhatian, termasuk radikalisme dan intoleransi. Hal ini dapat menimbulkan wajah suram dari umat beragama di ruang publik. Contohnya terlihat ketika konflik terbuka antar kelompok di gereja mengemuka di media sosial padahal di saat yang bersamaan, bom meledak di beberapa tempat (termasuk rumah ibadah) dan banyak korban yang membutuhkan pertolongan.

Kelima, hancurnya strategi edukatif dalam Pendidikan Kristiani karena model pendidikan yang dua arah dan dialogis tidak ditemui. Yang berkuasa tetaplah ide dominan yang menjadi racun bagi pembebasan. Hal ini terlihat melalui model pengajaran iman yang menekankan pada penyampaian doktrin yang menghakimi, menyalahkan atau bahkan menyudutkan orang-orang atau kelompok tertentu dalam pembinaan atau penyampaian Firman Tuhan.

15 Tran, 58. 


\section{Peran Penting Konsientisasi (Penyadaran) dan Praksis dalam Transformasi Sosial}

Salah satu pokok penting dalam partisipasi di ruang publik adalah kesadaran kritis. Proses untuk menumbuhkan kesadaran tersebut biasa dikenal dengan konsientisasi (penyadaran). ${ }^{16}$ Terinspirasi dari gagasan Paulo Freire, konsientisasi merupakan proses dalam pendidikan yang berperan dalam membangun sistem pendidikan bagi sebuah kebebasan yang otentik. Konsientisasi terjadi secara simultan bersamaaan dengan proses belajar ketika realita dibentangkan secara apa adanya, termasuk persoalan yang ada di dalamnya. ${ }^{17}$ Konsientisasi merupakan proses penting sehingga pendidikan dapat dilakukan secara holistik oleh setiap pihak yang terlibat tanpa paksaan dan tekanan. Ini adalah bentuk pendidikan yang membebaskan sebagai sebuah perangkat agar mereka yang terlibat di dalamnya menyadari dan mengetahui secara kritis bahwa baik diri mereka sendiri maupun sikap tidak peduli (atau abai) terhadap persoalan di ruang publik adalah pengejawantahan dari dehumanisasi. Para pembelajar diajak untuk memahami dan menyadari bahwa realitas penindasan merupakan situasi batas yang harus mereka ubah sebagai kekuatan penggerak bagi tindakan pembebasan itu sendiri. ${ }^{18}$

Dengan demikian, dapatlah dikatakan bahwa di dalam proses penyadaran juga terkandung praksis: refleksi dan tindakan atas dunia untuk mengubahnya. ${ }^{19}$ Pemaparan mengenai hubungan manusia-dunia dalam praksis dipahami sebagai hubungan dari kedua hal yang tidak mengada secara terpisah satu dengan yang lain. Keduanya mengada dalam hubungan dialektis secara ajeg. ${ }^{20}$ Praksis juga merupakan akar dari pendekatan transformasi sosial, yakni pendidikan bagi manusia sehingga mereka sadar akan keadaan mereka dan terlibat dalam perjuangan bagi kebebasan mereka. Untuk mencapai praksis ini, disyaratkan untuk memberi kepercayaan kepada seluruh pelaku pendidikan. ${ }^{21}$ Oleh sebab itu, deradikalisasi adalah bagian dari proses transformasi sosial. Di dalamnya proses pendekatan yang merangkul pihak-pihak yang terkait secara obyektif, termasuk di dalamnya suara penderitaan atau suara yang berasal dari korban radikalisme. Bagaimana perspektif mereka menjadi bagian yang penting dalam melihat persoalan secara menyeluruh. Misalnya saja, bagaimana umat Kristen melihat teroris, mantan teroris dan keluarganya tidak hanya sebagai orang jahat atau pemeluk agama Islam tapi sebagai sesama manusia.

Oleh karenanya, kajian terhadap hermenutika korban menjadi penting di sini. Terinspirasi dari tindakan transformatif Yesus yang memiliki korelasi dengan civil courage, meninggalkan posisi penonton dan mulai mengintervensi kejadian dan menyatakan ketidaksetujuannya secara publik. ${ }^{22}$ Dalam konteks deradikalisasi, proses ini dapat diterje-

\footnotetext{
${ }^{16}$ Konsientisasi mengacu pada proses di mana manusia, bukan sebagai resipien namun sebagai subyek yang mengetahui dan menyadari secara kritis dan mendalam kenyataan sosiokultural yang membentuk kehidupan mereka dan kemampuan untuk merubah kenyataan itu sendiri (memahami hubungan dialektis antara dirinya dan obyek secara kritis). Lih. Paulo Freire, Politik Pendidikan: Kebudayaan, Kekuasaan dan Pembebasan (Yogyakarta: Pustaka Pelajar, 1999), 166.

${ }^{17}$ Freire, 111.

${ }^{18}$ Paulo Freire, Pendidikan Kaum Tertindas (Jakarta: LP3S, 1985), 19.

${ }^{19}$ Freire, 22.

${ }^{20}$ Freire, 21.

${ }^{21}$ Freire, 43.

${ }^{22}$ Hardiman, Demokrasi dan Sentimentalitas: Dari “Bangsa Setan-Setan”, Radikalisme Agama sampai Post-Sekularisme, 166.
} 
mahkan sebagai keberpihakan pada korban radikalisme. Ini terkait dengan sikap Yesus yang menjungkirbalikkan tata kelola sosial yang dehumanitatif. Ia mengundang para korban sejarah yang disisihkan dari meja perjamuan untuk duduk bersama-Nya dalam satu meja perjamuan. ${ }^{23}$ Dengan demikian, panggilan bela rasa terhadap teroris, napi teroris, mantan napi teroris dan keluarganya tetap menjadi bagian dalam pendekatan transformasi sosial.

Dalam konteks Pendidikan Kristiani dapat dikatakan bahwa pendidikan dan pembinaan warga gereja amat diperlukan untuk membuat komunitas Kristen mampu mengemas "bahasa publiknya" sehingga isu deradikalisasi dapat tanggapi secara bernas dan bijak. Di dalamnya ada kepedulian tidak hanya terhadap korban teroris, tetapi juga teroris, napi teroris, mantan napi teroris dan keluarganya. Selain itu, isu deradikalisasi juga dapat dikorelasikan dengan persoalan kemanusiaan, keadilan serta intoleransi yang seringkali menghiasi wajah publik. Pendidikan dalam konteks komunitas iman inilah yang dilakukan dalam rangka "penyadaran" dan dalam konteks Pendidikan Kristiani, semangat transformasi sosial dapat digunakan melalui pendekatan yang holistik. Di dalamnya, arahan dan bimbingan melalui setiap program, pendidikan, pelayanan atau pembinaan umat dapat membuka wawasan tentang deradikalisasi serta perkembangannya dalam konteks yang ada. Umat juga didorong untuk menyuarakan aspirasi dan aksi kritisnya di ruang publik (termasuk surat kabar dan media social). Dalam proses ini, dialog antara rasio sekular dan agama dapat terbangun sehingga keserampangan rasio agama dan sekular yang berat sebelah harapannya tidak terjadi karena persoalan itu dapat membuahkan fanatisme berlebihan dan eksklusivitas serta radikalisme. Di sisi lain, rasio sekular dapat membuat sekularitas menjadi sesuatu yang dominan.

Muara pedagogi dalam proses ini adalah proses refleksi sebagai buah pembelajaran. Dengan demikian, partisipasi yang lahir di ruang publik bukanlah partisipasi yang membabi buta atau tergopoh-gopoh dilakukan. Warga jemaat dapat didorong untuk mewujudkan partisipasi holistik yang berkualitas. Hal ini amat dimungkinkan karena tema deradikalisasi juga memiliki keterkaitan erat dengan tema-tema tertentu yang dapat dikaji secara mendalam untuk konteks teologi dan interdisiplinaritas (misalnya tema tentang pasar dan birokrasi). Upaya ini kemudian akan melahirkan narasi kekristenan yang otentik dan relevan dalam menopang deradikalisasi. Di dalamnya, keramahan dengan kemanusiaan, resistensi terhadap dominasi kekuasaan dan kesediaan untuk mendengar "perspektif" yang lain menjadi penting untuk diperhatikan. ${ }^{24}$ Inilah yang membuat keterlibatan publik tidak hanya menjadi sesuatu tindakan euphoria atau sekadar toleransi semu di wajah publik, melainkan sungguh-sungguh menjadi sebuah virtue yang terinternalisasi dalam diri. Inilah sentuhan terhadap aspek spiritualitas yang membuat iman dan realitas menjadi sesuatu yang tidak terpisahkan dalam berteologi. ${ }^{25}$ Virtue yang dimaksud bukanlah sesuatu yang prematur dan murahan melainkan lahir dari proses yang terintegrasi dengan semua elemen pembelajaran. Dalam bahasa kurikulum, aspek eksplisit dan implisit tertuang di dalamnya.

${ }^{23}$ P. Mutiara Andalas, S.J., Kesucian Politik: Agama dan Politik di Tengah Krisis Kemanusiaan (Jakarta: Libri, 2008), 221.

${ }^{24}$ Wowor dan Yudhita, Wacana Deradikalisasi dalam Surat Kabar dan Kajian Teologi Praktis, 398.

${ }^{25}$ Emmanuel Gerrit Singgih, "Perumpamaan Perjamuan Besar sebagai Inspirasi bagi Revitalisasi dan Refungsionalisasi Warga Gereja GPIB dalam Masyarakat," GEMA 31, No. 2 (2007): 26, https://journaltheo.ukdw.ac.id/index.php/gema/article/view/64. 


\section{Teologi Publik dalam Konteks Indonesia}

Albertus Bagus Laksana mengemukakan pentingnya membangun teologi publik dalam konteks Indonesia. Ia menyebutnya dengan istilah teologi publik nusantara. ${ }^{26}$ Laksana mengemukakan, "kawasan kita [Indonesia] sekarang membutuhkan narasi-narasi bersama yang dibarui (shared renewed narratives), yaitu narasi yang berasal dari kerinduan hati kita, yang bisa memberi tenaga baru bagi kita yang menghuni kawasan ini. Kita bangkitkan lagi narasi-narasi mengenai campuran indah, hibriditas dan kemampuan untuk melihat karya Roh yang beraneka ragam yang kita warisi dalam banyak kultur di kawasan ini. Roh itulah yang menyatukan banyak hal yang berbeda dan membentuk jaringan-jaringan baru." ${ }^{27}$ Gagasan ini menunjuk pada upaya untuk mengembangkan dialog, interdisiplinaritas dan jejaring. Ini sejalan dengan karya Roh yang meluas dan merengkuh hal-hal baru. Ini adalah bagian dari kontemplasi yang terbuka bersama berdasarkan Pancasila dengan pihak lain dalam kedalaman rohani (pendidikan iman) dan intelektual kita. ${ }^{28}$

Senada dengan Laksana, Emmanuel Gerrit Singgih juga mengemukakan bahwa dalam upaya untuk membangun sebuah teologi publik di tengah tantangan konteks Indonesia masa kini, ada tiga muatan yang sebaiknya diperhatikan. Pertama, teologi yang menunjuk pada gambaran atau idea tentang Tuhan yang relevan dan kontekstual. ${ }^{29}$ Oleh karenanya perlu melihat warisan-warisan teologis yang telah diterima dari para pendahulu, misalnya Yohanes 3:16 yang berbicara tentang kasih Tuhan yang besar terhadap dunia ini. Namun, tetap perlu waspada dengan teologi triumfalis yang membuat kehilangan solidaritas dengan korban penderitaan yang ada di sekitar. Pokok kepercayaan juga perlu dipertajam secara kontekstual (misalnya pemahaman tentang Tritunggal), sehingga perjumpaan dengan agama lain, misalnya umat Islam, dapat membuat mereka dapat memahami kita ketika kita juga berusaha memahami mereka. ${ }^{30}$ Kedua, eklesiologi yang hendaknya tetap memperlihatkan identitas kita namun juga menampilkan keterbukaan dalam komunitas iman. Dalam perjamuan makan yang diadakan-Nya, Yesus mengajarkan tentang persekutuan yang inklusif, kekudusan berjalan bersama dengan bela rasa. ${ }^{31}$ Ketiga, misiologi. Eklesiologi yang terbuka menghasilkan misi yang terbuka pula. Teologi publik melihat Tuhan berada di dalam maupun di luar, di dunia ini. Itulah yang membuat persekutuan gereja yang ekslusif dan kaku menjadi terbuka dan menghadapkan wajah kita kepada publik. ${ }^{32}$ Ketiga komponen penting dalam teologi publik kontekstual di Indonesia ini menjadi dasar dalam pelaksanaan Pendidikan Kristiani untuk menunjang partisipasi umat di ruang publik.

\footnotetext{
${ }^{26}$ Albertus Bagus Laksana, "Membangun Teologi Publik Nusantara: Berkontemplasi dari Laut Tengah sampai Kepulauan Nusantara," Lectio Brevis dan Studium Generale Fakultas Teologi Universitas Sanata Dharma, Fakultas Teologi Wedabhakti, 2019/2020, n.d.

${ }^{27}$ Laksana.

${ }^{28}$ Laksana.

${ }^{29}$ Singgih menaruh tanda sambung di antara "teo" dan "logi" untuk "menunjukkan bahwa teologi di sini bukan merujuk pada pembicaraan umum mengenai teologi, tetapi pemahaman kita terhadap siapakah Tuhan dan Tuhan yang bagaimanakah yang menurut kita dapat menjawab tantangan-tantangan Indonesia masa kini." Emanuel Gerrit Singgih, Dari Ruang Privat ke Ruang Publik: Sebuah Kumpulan Tulisan Teologi Kontekstual Emanuel Gerrit SInggih, ed. August Corneles Tamawiwy (Yogyakarta: Kanisius, 2020), 379.

30 Singgih, 380 .

${ }^{31}$ Singgih, 381.

32 Singgih, 382.
} 


\section{Peran Pendidikan Kristiani untuk Menunjang Partisipasi di Ruang Publik}

Tujuan pengajaran dalam Pendidikan Kristiani adalah agar dampaknya terasa dalam komunitas. Komunitas dalam hal ini bukan hanya komunitas iman atau gereja melainkan juga masyarakat. Peran advokasi juga terlihat ketika Pendidikan Kristiani diharapkan "to educate the public and provide resources to church groups to explore contemporary public issues. "33 Selain tiga muatan teologi, eklesiologi dan misiologi yang dipaparkan Singgih dalam kajian teologi publik, ada tiga hal penting yang perlu diperhatikan di sini yakni identitas, vokasi dan sumber daya. Identitas berbicara tentang siapa diri kita, vokasi terkait dengan tindakan apa yang kita lakukan dalam menanggapi situasi yang ada di sekitar kita dan sumber daya adalah setiap hal yang kita miliki dan dapat digunakan untuk memberikan kontribusi dalam kehidupan, termasuk di dalamnya beberapa keahlian yang penting untuk diperhatikan. ${ }^{34}$ Terkait dengan identitas, penting bagi kita untuk memahami warisan iman sebagai sesuatu yang membentuk keyakinan di dalamnya kajian teologi tetap memegang peranan yang penting. Itulah yang akan membuat kita mampu untuk mengoptimalkan sumber daya yang kita miliki untuk melakukan tindakan yang tepat dalam menanggapi konteks yang ada di sekitar.

Keberadaan Pendidikan Kristiani di ruang publik dipayungi oleh semangat transformatif. Dengan demikian, Pendidikan Kristiani tidak hanya dijalankan untuk gereja atau komunitas iman melalui kegiatan pengajaran dan pembinaan umat, melainkan juga dalam keterlibatan aktif umat di tengah masyarakat. Proses pembelajaran terjadi ketika umat menjadi rekan sekerja Allah yang berbela rasa untuk menjangkau dunia dengan pelayanan kepedulian, keadilan, dan transformasi. ${ }^{35}$ Di dalamnya ada proses aksi dan refleksi yang memungkinkan transformasi terjadi. Transformasi tidak hanya terwujud dalam pelayanan yang dilakukan, melainkan juga ketika diri kita sendiri mengalami transformasi. ${ }^{36}$

Iman Kristen harapannya dapat sungguh-sungguh terlihat perannya dalam proses transformasi di tengah masyarakat. Salah satu unsur yang penting dalam pendekatan ini adalah pengajar. Untuk menciptakan tujuan pembelajaran yang menghasilkan transformasi melalui keadilan dan damai sejahtera, pengajar harus terlebih dulu menghadirkannya dalam dirinya sendiri dan dapat dirasakan saat ia mengajar. Pelajar dilihat sebagai subyek yang bersama-sama dengan pengajar perlu mengalami perubahan epistemologis karena apa yang sebelumnya belum "terlihat" atau "tersadari" dalam realitas dapat dilihat dengan lebih jernih dan dalam ketika iman dapat dimanifestasikan dalam kehidupan sehari-hari. ${ }^{37}$ Inilah yang disebut dengan kontinuitas dari perspektif rekonstruksionis dalam pendidikan: "pendidikan meningkatkan kesadaran murid terhadap kebutuhan komunal, transformasi sosial, dan memampukan mereka untuk berpartisipasi dalam perubahan yang terjadi." 38 Secara teologis,

\footnotetext{
${ }^{33}$ Jack L. Seymour, Teaching the Way of Jesus: Educating Christians for Faithful Living (Nashville: Abingdon Press, 2014), 34.

${ }^{34}$ Seymour, 39-40.

35 Jack L. Seymour, "Pendekatan-Pendekatan Pendidikan Kristiani,” dalam Memetakan Pendidikan Kristiani: Pendekatan-Pendekatan Menuju Pembelajaran Jemaat, ed. Jack L. Seymour (Jakarta: PT BPK Gunung Mulia, 2016), 15.

36 Seymour, 15.

${ }^{37}$ Daniel Schipani, "Pendidikan Transformasi Sosial," in Memetakan Pendidikan Kristiani: PendekatanPendekatan Menuju Pembelajaran Jemaat, ed. Jack L. Seymour (Jakarta: BPK Gunung Mulia, 2016), 28.

38 Schipani, 29.
} 
kita menjadi semakin humanis melalui tranformasi yang kita lakukan karena di dalamnya kita sebagai warga negara berpartisipasi dalam karya kreatif, membebaskan dan memperbarui karya Allah di dunia. ${ }^{39}$ Konsep ini memiliki korelasi kuat dengan kewarganegaraan yang dapat menambah kualitas kehidupan seorang murid Kristus di tengah masyarakat karena solidaritas untuk hadir di tengah dunia semakin kokoh atas keyakinan dari kekuatan rahmat Allah. Rahmat Allah pula yang membuat kita menjadi rendah hati. Harapannya adalah proses ini dapat membawa pembebasan dan harapan karena transformasi yang Ia nyatakan. Hal ini adalah sebuah proses yang memiliki dampak besar karena keberadaan Allah di tengah sejarah kehidupan terintegrasi dengan pendidikan jemaat.

\section{Pendekatan Pendidikan Kristiani dalam Menunjang Partisipasi di Ruang Publik}

Dalam semangat transformasi untuk mewujudkan kehadiran umat Kristen di ruang publik, tiga muatan teo-logi, eklesiologi dan misiologi yang dipaparkan Singgih dalam kajian teologi publik memiliki korelasi erat dengan tiga pendekatan Pendidikan Kristiani dari Seymour, komunitas iman, instruksional, dan misi. Pendekatan komunitas iman terkait dengan muatan eklesiologi, pendekatan instruksional memiliki korelasi dengan muatan teo-logi, dan pendekatan misi terkait dengan muatan misiologi. Pertama, komunitas iman. Komunitas iman memiliki peran amat kuat untuk mengajarkan pentingnya partisipasi umat Kristen di ruang publik. Di dalamnya setiap orang dirangkul dalam keramahan komunitas, merasakan toleransi secara nyata, merayakan kebersamaan dan kepelbagaian serta membangun percakapan atau dialog dalam rangka belajar dan berefleksi bersama sebagai bentuk dukungan untuk berpartisipasi di ruang publik. Di dalamnya ada perjumpaan dan relasi yang saling menguatkan dan mengisi untuk kemudian memantapkan kehadiran seseorang di ruang publik. Model pembelajaran yang juga tidak kalah penting untuk diperhatikan adalah pembelajaran kelompok sebagai metode dalam proses yang transformatif. Mengingat radikalisme juga rentan memberikan pengaruh bagi kaum muda, pembelajaran kelompok menjadi metode yang efektif untuk melatih dan mengembangkan empati. ${ }^{40}$ Tekanannya tidak hanya pada kekudusan, melainkan juga bela rasa. Kelompok dalam konteks pelayanan kaum muda menjadi sarana efektif untuk belajar memahami orang lain asalkan dijalankan dengan kemampuan edukatif yang mumpuni. Sebaliknya, dalam kekeliruan indoktrinasi terhadap perasaan "kita" dan "bukan kita" juga dapat mengusung radikalisme yang melahirkan dukungan pada "kita" dan perasaan kebencian yang kuat pada yang "bukan kita". ${ }^{41}$

Kedua, instruksional. Landasan pemikiran dalam pembelajaran iman amat penting untuk menghadirkan dasar pemahaman iman dalam partisipasi di ruang publik. Membaca realita dengan dasar warisan iman adalah bagian dari proses transformasi. Di dalamnya, hikmat Allah perlu menerangi proses penafsiran kita atas realita termasuk juga perspektif Alkitab yang dikaji dengan mendalam. Tidak hanya itu, sumber lain dalam iman Kristen dan

${ }^{39}$ Schipani, 33.

${ }^{40}$ David Howe, Empati: Makna dan Pentingnya (2015), 11, dikutip dalam Jeniffer F. P. Wowor, "Kubus Iman dan Dialog Antar Umat Beragama: Sebuah Upaya Membangun Kesadaran Relasional Antara Aku, Kamu dan Kita," dalam Menuju Perjumpaan Otentik Islam-Kristen, ed. Wahyu Nugroho dan Djoko Prasetyo (Yogyakarta: Taman Pustaka Kristen, 2010), 36.

${ }^{41}$ Foster di kutip Seymour dalam Seymour, Teaching the Way of Jesus: Educating Christians for Faithful Living, 72. 
tradisi (warisan teologis) perlu dikorelasikan dalam penafsiran yang holistik (misalnya ajaran tentang pembebasan, keadilan, toleransi dan damai sejahtera) melalui khotbah, pendalaman Alkitab, maupun pembinaan. Dalam proses ini jembatan dengan pemahaman iman komunal pun dapat dikorelasikan dengan suasana yang saling menghormati dan menghargai kepelbagaian pendapat yang ada.

Ketiga, misi kepada masyarakat. Aksi nyata menjadi upaya untuk mengimplementasikan dan mengevaluasi praktik yang dilaksanakan dalam rangka membela kemanusiaan. Proses ini mengarah pada praksis lanjutan dan bertanggung jawab dalam keterlibatan langsung di ruang publik sebagai bagian dari proses pembelajaran yang membebaskan demi mewujudkan keadilan dan perdamaian. Dalam pendekatan ini, ada ruang yang diberikan bagi komunitas Kristen untuk menerjemahkan bahasa teologis mereka yang partikular ke dalam ungkapan yang dapat diterima secara rasional oleh publik. Wajah umat dengan demikian juga dihadapkan kepada publik. Hal ini penting untuk diperhatikan khususnya dalam menghadapi maraknya aksi radikal dan intoleran di sekitar kita. Dalam pengertian inilah pendekatan misi dalam Pendidikan Kristiani ditawarkan dengan pemahaman bahwa pendekatan ini erat kaitannya dengan komunitas iman dan landasan instruksional yang penting dalam menunjang pendekatan misi.

Ada tiga tugas penting yang harus dilakukan dalam proses ini, yakni ${ }^{42}$ : Pertama, keterlibatan publik. Dalam proses ini, kepekaan terhadap perwujudan nilai-nilai pemerintahaan Allah yang diejawantahkan dalam ruang publik adalah sesuatu yang amat penting. Dengan demikian, kepiawaian untuk melihat realita akan membuat kita tidak mengabaikan persoalan dalam konteks yang dihidupi. Kita juga dapat "mendengar" suarasuara penderitaan menjadi amat penting dalam konteks radikalisme, korban dari tindakan radikal (termasuk terpidana teroris, mantan teroris, keluarga dan korban) perlu mendapatkan perhatian. Membangun akses dengan ruang publik juga amat penting melalui relasi dengan tokoh-tokoh masyarakat yang memiliki peran untuk mengambil kebijakan publik.

Kedua, mempersiapkan komunitas Kristen untuk terlibat di ruang publik. Pembelajaran perlu diberikan dalam komunitas iman melalui studi teologis dan biblis tidak hanya dalam konteks gereja, melainkan juga Pendidikan Agama Kristen di sekolah dan masyarakat (misalnya melalui lembaga swadaya masyarakat). Kekerasan, intoleransi dan radikalisme adalah realita yang perlu dikaji dalam perspektif teologis dan biblis dalam keragaman konteks pembelajaran. Hal itu tentu akan diteruskan dalam implikasi yang tepat guna dalam menjawab persoalan dan luka yang muncul karena radikalisme dan intoleransi yang seringkali memenuhi ruang-ruang kehidupan masyarakat Indonesia saat ini. Tanpa kajian teologis dan biblis, umat Kristen dapat kehilangan energi untuk melakukan maksud baik dan tindakan mulia tanpa memiliki landasan spiritual yang kokoh. Melalui proses ini, komunitas iman siap untuk berdialog dalam ruang publik karena memiliki landasan pemikiran yang utuh dan mendalam tanpa harus kehilangan identitas karena punya dasar kokoh dalam perspektif imannya.

\footnotetext{
${ }^{42}$ Seymour, 176-81.
} 
Ketiga, menjadi teladan dalam iman sebagai bentuk pengajaran yang sejati. Keteladanan iman Kristen adalah sesuatu yang amat penting untuk membuat orang-orang di sekitar kita dapat merasakan apa sesungguhnya nilai-nilai Kerajaan Allah yang sejati. Umat Kristen, tidak hanya berbicara tentang kasih, tapi juga menunjukkan kasih secara nyata. Umat Kristen tidak hanya menggemakan pentingnya bersikap toleran tapi juga menunjukkan sikap toleran yang sejati seperti apa bentuknya. Hal ini adalah sesuatu yang amat krusial dalam pendidikan Kristiani. Di dalamnya, proses belajar terjadi ketika keteladanan iman tidak hanya diketahui melainkan juga dirasakan. Inilah proses bertindak secara nyata yang juga penting untuk mengusung sebuah transformasi sosial. Suatu kesadaran akan realitas semata-mata tanpa teladan nyata tidak akan mengarah kepada perubahan realitas itu.

\section{Pendidikan Kristiani untuk Menunjang Partisipasi di Ruang Publik: Sebuah Pengembangan Pemikiran dalam Konteks Lintas Iman di Indonesia}

Dalam pembahasan tentang terorisme global, peran komunitas lintas iman adalah hal yang penting. Semangat transformasi yang telah dikemukakan dalam tulisan ini seyogianya dapat pula memberikan perhatian terhadap konteks kepelbagaian agama dan kepercayaan yang ada di Indonesia. Kesadaran pluralis tidak hanya dibutuhkan oleh orang Kristen, tapi oleh semua masyarakat Indonesia. Kesadaran ini menolong semua orang untuk dapat saling menghargai dan menghormati. ${ }^{43}$ Oleh karenanya, melengkapi kajian tentang paparan yang telah dilakukan Seymour, penulis juga hendak mengembangkannya dalam konteks kepelbagaian agama dan kepercayaan di Indonesia. Gagasan ini tentu diberikan dengan tidak mengabaikan pentingnya upaya gereja untuk mendidik dan membina warganya dalam kebersamaan di tengah komunitas iman dan melalui warisan iman (instruksional) untuk mengembangkan pelayanan misi. Setiap pribadi adalah bagian penting dari warga jemaat dan warga negara. Semua memiliki ruang yang sama untuk mengekspresikan sikap yang aktif, kritis dan konstruktif dalam partisipasi mereka di ruang publik. Dalam partisipasi ini, jaringan intra dan interreligius dapat terbangun pula dalam keterlibatan kritis dan obyektif atas isu radikalisme dan intoleransi. Inilah peran penting dari Pendidikan Kristiani yang menunjang partisipasi di ruang publik. Dalam ruang publik, perjumpaan dengan umat dengan agama dan kepercayaan yang berbeda dapat tercipta. Harapannya, proses saling belajar dan memperkaya satu sama lain dapat terwujud dalam proses ini. ${ }^{44}$

Lebih lanjut, dalam konteks lintas iman, tahapan yang dapat dikembangkan adalah sebagai berikut: Pertama, perjumpaan komunitas lintas iman. Komunitas Kristen (diharapkan tidak hanya pemimpin umat tetapi juga warga jemaat) berjumpa dengan komunitas agama lain (lintas iman) untuk melihat realita dalam konteks yang dihidupi serta persoalan yang ada di dalamnya. Komunitas-komunitas iman ini diharapkan dapat bersama "mendengar" suarasuara penderitaan dari persoalan intoleransi, radikalisme yang masalah-masalah yang terkait dengan isu kekerasan ini.

\footnotetext{
${ }^{43}$ Justitia Vox Dei Hattu, Mewarga Dengan Hati: Pembelajaran Transformatif sebagai Respons Pedagogis Kristiani terhadap Tantangan Pendidikan Kewarganegaraan dalam Konteks Indonesia Masa Kini (Jakarta: BPK Gunung Mulia, 2018), 46.

${ }^{44}$ Jeniffer Pelupessy-Wowor, "The Role of Religious Education in Promoting Religious Freedom: A Mutual Enrichment between 'My Story,' 'Your Story,' and 'Our Stories,'” The Review of Faith and International Affairs 14, no. 4 (2016): 104, https://doi.org/10.1080/15570274.2016.1248527.
} 
Kedua, pendekatan instruksional lintas iman. Pendekatan Instruksional yang dikemukakan Seymour dapat dikembangkan dalam konteks di mana dua atau lebih komunitas iman dapat diberi ruang untuk mengkaji kitab suci masing-masing untuk menopang kajian atas persoalan yang dilihat dalam proses sebelumnya. Tentu setiap komunitas iman tidak diminta untuk meninggalkan identitas mereka sebagai pemeluk agama dalam perjumpaan dengan komunitas dari agama yang berbeda. Misalnya saja, untuk komunitas Kristen, keterlibatan kita untuk memperjuangkan deradikalisasi di ruang publik harus dilandaskan pada pengakuan iman kita bahwa Yesus Kristus adalah Tuhan. Itu artinya, segala upaya kita untuk memperjuangkan deradikalisasi bukanlah untuk memuliakan diri kita sendiri melainkan memuliakan Kristus yang adalah Tuhan. ${ }^{45}$ Setelah itu, nilai ini menjadi landasan untuk menganalisis persoalan yang muncul dari perspektif kristiani. Hal yang sama juga berlaku dari perspektif agama lain. Dari proses inilah maka implikasi yang tepat guna dan holistik dapat tercapai dalam upaya menjawab tantangan radikalisme dan intoleransi. Setiap komunitas juga dapat melihat nilai-nilai penting yang menunjang deradikalisasi dalam kajian teologis ini.

Ketiga, pelaksanaan misi lintas iman. Komunitas iman dari agama yang berbeda diharapkan dapat membangun dialog untuk saling memperkaya satu sama lain ketika realita persoalan itu dibentangkan sebagai tantangan yang harus dicermati bersama. Proses menilai realita secara kritis juga dimunculkan dari kesadaran dari setiap komunitas religious atas realita yang dihadapi serta posisi masing-masing komunitas di dalam realitas tersebut. Misalnya saja untuk persoalan radikalisme dan intoleransi, setiap komunitas dapat memahami bahwa peran mereka amat berkontribusi amatlah penting di dalam proses deradikalisasi. Selain itu, setiap komunitas tidak hanya saling mendapat manfaat dalam perjumpaan interreligius ini tapi juga saling belajar daripadanya. Saat setiap komunitas iman melihat secara langsung realita yang dibentangkan, kesadaran kritis diharapkan muncul bahwa persoalan radikalisme dan intoleransi serta upaya deradikalisasi untuk mengatasi persoalan tersebut memiliki kaitan dengan keberadaan komunitasnya sendiri. Setiap komunitas kemudian ia diajak untuk menghadapi realita tersebut secara kritis serta bertindak terhadapnya. Proses mengejawantahkan tindakan secara nyata menjadi penting dalam menghadirkan sebuah transformasi sosial (dalam hal ini deradikalisasi). Suatu kesadaran tanpa tindakan kritis akan menjadi sesuatu yang tidak memiliki dampak dalam konteks ruang publik.

\section{Kesimpulan}

Pendidikan Kristiani memiliki peran yang amat penting dalam menunjang partisipasi komunitas Kristen di ruang publik dalam rangka deradikalisasi. Melalui peran komunitas iman, kajian mendalam atas warisan iman, dan tindakan misi yang mendorong komunitas iman untuk melibatkan diri secara nyata dalam tantangan intoleransi dan radikalisme, harapannya ada kontribusi yang dapat diberikan oleh umat Kristen di ruang publik. Dengan demikian, Pendidikan Kristiani untuk partisipasi di ruang publik dapat menjadi bentuk pendekatan transformasional dalam upaya untuk menghadirkan manfaat pendidikan iman di ruang publik.

${ }^{45}$ Paulus S. Widjaja, "Partisipasi Kristiani dalam Politik di Indonesia: Antara Mitos, Realita dan Politik Yesus," GEMA 38, no 2 (2014): 141. 
Pengembangan kajian dalam konteks lintas iman turut memperkaya hasil pembahasan dalam tulisan ini. Dalam pembahasan tentang terorisme global, peran komunitas lintas iman adalah hal yang penting. Semangat transformasi yang telah dikemukakan dalam tulisan ini seyogianya dapat pula memberikan perhatian terhadap konteks kepelbagaian agama dan kepercayaan yang ada di Indonesia. Kesadaran pluralis tidak hanya dibutuhkan oleh orang Kristen, tapi oleh semua masyarakat Indonesia. Kesadaran ini menolong semua orang untuk dapat saling menghargai dan menghormati dan tentu akan memberi dampak yang berarti dalam proses deradikalisasi.

Model pendidikan ini adalah sebuah bentuk dari banyak ragam kekayaan pendekatan lainnya dalam upaya untuk menghadirkan manfaat pendidikan iman di ruang publik khususnya dalam menunjang proses deradikalisasi. Hal ini tentu dapat diperkaya oleh akademisi atau praktisi pendidikan dalam kajian lanjutan interdisipliner melalui pendekatanpendekatan bagi mereka yang menjadi "korban" radikalisme dan intoleransi karena persoalan ini perlu didekati secara holistik. Oleh karenanya, kontribusi dari bidang lain, misalnya pendekatan personal yang memuat aspek pastoral dan kajian psikologis menjadi menarik untuk ditelaah lebih dalam. Tentu dalam setiap upaya ini terkandung harapan bahwa distorsi komunikasi yang mewarnai ruang publik yang berduka karena radikalisme dan intoleransi dapat mengalami sebuah proses transformatif demi kesejahteraan bersama dalam masyarakat Indonesia.

\section{Referensi}

Andalas, S.J., P. Mutiara. Kesucian Politik: Agama dan Politik di Tengah Krisis Kemanusiaan. Jakarta: Libri, 2008.

Fatlolon, Constantinus. Masalah Terorisme Global: Dalam Konteks Teori Habermas tentang Kolonisasi Dunia Kehidupan oleh Sistem Modern. Yogyakarta: Kanisius, 2016.

Freire, Paulo. Pendidikan Kaum Tertindas. Jakarta: LP3S, 1985.

- Politik Pendidikan: Kebudayaan, Kekuasaan dan Pembebasan. Yogyakarta: Pustaka Pelajar, 1999.

Hardiman, F. Budi. Demokrasi dan Sentimentalitas: Dari “Bangsa Setan-Setan”, Radikalisme Agama sampai Post-Sekularisme. Yogyakarta: Kanisius, 2018.

Hattu, Justitia Vox Dei. Mewarga dengan Hati: Pembelajaran Transformatif sebagai Respons Pedagogis Kristiani terhadap Tantangan Pendidikan Kewarganegaraan dalam Konteks Indonesia Masa Kini. Jakarta: BPK Gunung Mulia, 2018.

Laksana, Albertus Bagus. "Membangun Teologi Publik Nusantara: Berkontemplasi dari Laut Tengah sampai Kepulauan Nusantara." Lectio Brevis dan Studium Generale Fakultas Teologi Universitas Sanata Dharma, 2019/2020, Fakultas Teologi Wedabhakti, n.d.

Oetomo, Dèdè. "Penelitian Kualitatif: Aliran Dan Tema." Dalam Metode Penelitian Sosial: Berbagai Alternatif Pendekatan, Bagong Suyanto and Sutinah (ed.), 3rd ed. Jakarta: Kencana, 2007.

Pelupessy-Wowor, Jeniffer. "The Role of Religious Education in Promoting Religious Freedom: A Mutual Enrichment between 'My Story,' 'Your Story,' and 'Our Stories.'” The Review of Faith and International Affairs 14, no. 4 (2016): 98-106. https://doi.org/10.1080/15570274.2016.1248527.

Schipani, Daniel. "Pendidikan Transformasi Sosial." Dalam Memetakan Pendidikan Kristiani: Pendekatan-Pendekatan Menuju Pembelajaran Jemaat, Jack L. Seymour (ed.). Jakarta: BPK Gunung Mulia, 2016. 
Seymour, Jack L. "Pendekatan-Pendekatan Pendidikan Kristiani.” Dalam Memetakan Pendidikan Kristiani: Pendekatan-Pendekatan menuju Pembelajaran Jemaat, Jack L. Seymour (ed.). Jakarta: PT BPK Gunung Mulia, 2016.

. Teaching the Way of Jesus: Educating Christians for Faithful Living. Nashville: Abingdon Press, 2014.

Singgih, Emanuel Gerrit. Dari Ruang Privat ke Ruang Publik: Sebuah Kumpulan Tulisan Teologi Kontekstual Emanuel Gerrit Singgih. August Corneles Tamawiwy (ed.). Yogyakarta: Kanisius, 2020.

_. "Perumpamaan Perjamuan Besar sebagai Inspirasi Bagi Revitalisasi dan Refungsionalisasi Warga Gereja GPIB dalam Masyarakat.” GEMA 31, No. 2 (2007): 18-28. https://journal-theo.ukdw.ac.id/index.php/gema/article/view/64.

Suardana, I Made. "Mengurai Landasan Konseptual Pendidikan Agama Kristen Multikultural dalam Konteks Indonesia." Kurios 6, no. 2 (2020): 346-66. https://doi.org/https://10.30995/kur.v6i2.150.

Tran, Mai-Anh Le. Reset the Heart: Unlearning Violence, Relearning Hope. Nashville: Abingdon Press, 2017.

Widjaja, Paulus S. "Partisipasi Kristiani dalam Politik di Indonesia: Antara Mitos, Realita dan Politik Yesus." GEMA 38, no 2 (2014).

Wowor, Jeniffer F. P. "Kubus Iman dan Dialog Antar Umat Beragama: Sebuah Upaya Membangun Kesadaran Relasional antara Aku, Kamu dan Kita.” Dalam Мenијu Perjumpaan Otentik Islam-Kristen, Wahyu Nugroho dan Djoko Prasetyo (ed.). Yogyakarta: Taman Pustaka Kristen, 2010.

Wowor, Jeniffer F. P., dan Rena Sesaria Yudhita. Wacana Deradikalisasi dalam Surat Kabar dan Kajian Teologi Praktis. Yogyakarta: Duta Wacana University Press, 2019. 